\title{
Structural Model of Developing Human Resources Performance: Empirical Study of Indonesia States Owned Enterprises*
}

\author{
Siti HAERANI ${ }^{* *}$, SUMARDI $^{* * *}$, Wardhani HAKIM $^{* * * * *}$, HARTINI $^{* * * * *}$, \\ Aditya Halim Perdana Kusuma PUTRA ${ }^{* * * * * *}$
}

Received: January 06, 2020 Revised: January 30, 2020 Accepted: February 06, 2020.

\begin{abstract}
This study aims to analyze the effect of structural Person-Organization Fit and organizational justice on organizational commitment, job satisfaction, Organizational Citizenship Behavior and employee performance. This study is based on a quantitative approach by collecting data using a survey conducted on three SOE's companies in Indonesia that operate in Makassar City, namely Pelindo. Ltd (Port Company), PLN. Ltd (Electric Company) and Pertamina. Ltd (Oil and Gas Company), with a sample of 90 employees. The study population was all non-managerial permanent employees. Data analysis using Structural Equation Modeling. In structural relations, out of the nine direct tests, there were two insignificant relationships, and in all three hypotheses there was one not-supported hypothesis. When compared between person-organization Fit and Organizational Justice, it is found that organizational justice has a more critical role in building Human Resource performance compared to Person-Organization Fit, because organizational justice is better able to provide job satisfaction and make organizational commitment and OCB as a prerequisite for its formation to better Human Resources performance. With organizational justice, employees will feel more satisfied working, committed to the work and organization, and behaves as a supportive organizational citizen for the realization of the best performance for the interests of the organization going forward.
\end{abstract}

Keywords : Person-Organization Fit, Organizational Justice, Organizational Commitment, OCB, Work Satisfaction, Indonesia.

JEL Classification Code: L20, J3, M0.

\section{Introduction}

*Thanks to the Ministry of Research Technology and Higher Education of Indonesia (RISTEK-DIKTI) through Simlitabmas research funding, thanks also to co-authors, reviewers, and editors, as well as to the Rector, Dean and Research and Community Service Institute (LPPM) of Universitas Hasanuddin - Makassar, Indonesia Faculty of Economics and Business.

${ }^{* *}$ First Author. Professor, Department of Management, Faculty of Economics and Business, Universitas Hasanuddin, Indonesia. Email: haeranisiti68@yahoo.co.id

***Associate Professor, Department of Management, Faculty of Economics and Business, Universitas Hasanuddin, Indonesia

${ }_{* \star * \star A}$ Assistant Professor, Department of Management, Faculty of Economics and Business, Universitas Hasanuddin, Indonesia

$* * * * *$ Associate Professor, Department of Economics Science, STKIP Pembangunan Indonesia, Indonesia

${ }^{* * * * * *}$ Corresponding Author. Assistant Professor, Department of Management, Faculty of Economics and Business, Universitas Muslim Indonesia, Makassar, Indonesia [Postal Address: Jalan Tamalate 1 Tidung 4 Number 143, Makassar City, South Sulawesi, 90222, Indonesia] Tel. +6282292222243,

Email: adityatrojhan@gmail.com
The still-popular issue of corruption, collusion and nepotism (KKN) within Indonesian SOE's (States Owned Enterprises) (CNN Indonesia, 2019), allows the problem of objectivity in the process of human resource management, including in the process of recruitment, selection, and placement of employees as well as in the system of giving awards to employees. Recruitment, selection, and placement systems that are not carried out objectively can have an impact on the placement of people who are not suited to the job or organization (Singh, Attri, Kanti-Das, Jaiswal, \& Jaiswal, 2019; Brass, 1984). Likewise, a system of employee rewards or compensation that is not well managed can lead to employee dissatisfaction with salary issues (Sha, Li, Law, \& Yip, 2019), as well as benefits and incentives received both in terms of the amount of take-

(c) Copyright: The Author(s)

This is an Open Access article distributed under the terms of the Creative Commons Attribution Non Commercial License (https://creativecommons.org/licenses/by-nc/4.0/) which permits unrestricted non commercial use, distribution, and reproduction in any medium, provided the original work is properly cited. 
home-pay they get and the manner or process of determining the compensation which can be seen by employees as a matter of injustice in terms of compensation (Hirschi, Herrmann, Nagy, \& Spurk, 2016; Robst \& VanGilder, 2016; Mattingly \& Boyle, 2019). Therefore, it is interesting to study in this study regarding the suitability of HR with work as well as the values and goals of the organization (Person-Organization fit) (Choi, Kim, \& McGinley, 2017; Deniz, Noyan, \& Ertosun, 2015; Afsar, Badir, \& Khan, 2015; Yu, 2014; Saether, 2019), while for the aspect of appreciation to employees, what is relevant is the fairness of the organization in providing rewards (career and financial) to its employees for the performance they have contributed (Yilmaz \& Chen, 2009).

The argument supporting the importance of this research is that an unsuitable employee placement system will give birth to employees who are incompetent and dissatisfied and not committed and will not even have OCB at work; as a result, their performance will be low (Shin \& Hur, 2019; Nohe \& Michaelis, 2016; Nazir, Shafi, Qun, Nazir, \& Tran, 2016; Farooqui \& Nagendra, 2014; Kristof-Brown, Zimmerman, \& Johnson, 2005). Likewise, if employees are not valued fairly and relatively both financially and nonfinancially (career) then they will also feel dissatisfaction at work, no commitment or behavior to refer to Organizational Citizenship Behavior (OCB) is complicated to expect so that SOE's performance can continue degenerate (Ibrahim, 2014; Ibrahim \& Aslinda, 2013; Maysarah \& Rahardjo, 2015). Thus, if the SOE's is not supported by people having the fit competency or not valued relatively and reasonably, the optimal performance will be challenging to achieve.

Research on person-organizational fit and organizational justice is the theme of organizational behavior studies that have attracted the attention of previous researchers such as (Liu, Tang, \& Yang, 2015; Saether, 2019; Choi et al., 2017; Deniz et al., 2015). However, in the context of SOE organizations it is still lacking, so that it has excellent potential to generate new information related to the negative implications of not fulfilling the principle of employee placement "the right man on the right place" or "unfit" and the law of fairness in payroll (Equity) in an organization. The descriptions above are the main reason for the importance of this study, to re-examine the suitability of people with the organization and their work, especially if combined with the perception of organizational justice in valuing employees can improve the performance of employees contributed to the organization. Through job satisfaction and perceived organizational commitment, as well as voluntary behavior of employees at work, especially for state-owned organizations.

This study has a specific purpose of understanding the variables that are important determinants of employee performance as a proxy for the SOE performance organizations in the future. Considering that SOE is one of the backbones of the economy and state finances, as an engine of development financing in all fields, for the sake and benefit of the nation through its vital function to provide and provide services to the needs of the community, SOEs should be sustained to develop their performance continuously. Thus, the results of this study are expected to make practical contributions in the form of information or recommendations about the improvements needed, especially from the aspects of Human Resource Management and employee behavior.

Besides, this research is also expected to contribute to the development of knowledge, primarily related to the extent of suitability of people with the organization and organizational justice can be used as an intervention variable to develop job satisfaction, organizational commitment and Organizational Citizenship Behavior (OCB) as an essential determinant of the performance of SOE's employees. Innovative findings and outcomes targeted from this research are new information about the main determinants of the performance of SOE's employees that can be used as a practical basis for the development of SOE performance in the future and a theoretical foundation for the development of science, especially in the field of Human Resource Management (Recruitment System, Placement and Rewards or employee compensation) and Organizational Behavior (Job satisfaction, organizational commitment, OCB and employee performance as measures of organizational effectiveness). The study of personorganization Fit, organizational justice, job satisfaction, and organizational commitment and OCB is a study in the field of organizational behavior, which is very important because it combines individual aspects and regulatory aspects as a determinant of employee and organizational performance, especially in SOEs in Indonesia.

Aspects of the organization are identified through Person-Organizational Fit, which reflects the extent to which the practice of recruitment and placement of employees is carried out appropriately based on the suitability of competencies, goals, and values held between individuals and organizations (Özçelik \& Fındıklı, 2014). Other aspects of the organization are identified through organizational justice variables that reflect the extent to which the practice of rewards or compensation provided by the organization is felt somewhat by employees. (Akram, Lei, Haider, \& Hussain, 2019; Pérez-Rodríguez, Topa, \& Beléndez, 2019). While individual aspects will be identified through job satisfaction, organizational commitment, Organizational Citizenship Behavior (OCB) and performance contributed by employees to their organizations, so this research is fundamental and different from previous studies on the same both in terms of scope and the organization that is the object of study. The findings 
of this study will undoubtedly contribute to the development of science, especially in the field of organizational behavior and human resource management.

\section{Literature Review}

\subsection{Person-Organization Fit, Job Satisfaction, Organizational Commitment, OCB, and Employee Performance}

Kristof (1996) stated that person-organization Fit can be interpreted as value congruence, goal congruence, employee, needs fulfillment, and culture personality congruence. Individuals who have the same values as the organization, they will easily interact efficiently with the organization's value system, reduce uncertainty, and conflict and increase satisfaction and commitment, and improve performance - the employee. The interaction between Person-Organization Fit variables and positive employee performance shows that the application of person-organization Fit will enhance employee performance. (Kristof, 1996; Farooqui \& Nagendra, 2014; Tepeci, 2001). Individuals are interested and feel comfortable in an organization because of the similarity in characteristics between the two so that it has a substantial impact on improving performance (Hoendervanger, Van Yperen, Mobach, \& Albers, 2019; Jung, 2020; Sharma \& Stol, 2020; Bagozzi \& Verbeke, 2019). Research by Saether (2019) supports the influence of Person-Organization Fit on job satisfaction and performance. However, there is research. (Daugherty, Chen, \& Ferrin, 2011; Dougherty \& Kurke, 2003) which did not find any influence on the Fit Person-Organization job satisfaction on employees.

\subsection{Effect of Organizational Justice on Job Satisfaction, Organizational Commitment, OCB and Employee Performance}

Study results from Cohen-Charash and Spector (2001) show that organizational justice plays an essential role in the formation of various attitudes such as satisfaction and commitment, as well as behaviors such as performance, extra-role behavior, and counterproductive behavior. Fairness plays an essential role in the organization because it will affect employee beliefs, feelings, attitudes, and practice. The treatment being fairleads to higher efficiency and commitment in the organization. On the other hand, people who feel that there is injustice in the organization, in general, are more likely to leave the organization or employees working with a low level of efficiency, deviant behavior such as revenge.
Emami, Alizadeh, Nazari, and Darvishi (2012) mentions some variables that become antecedents or that affect OCB as positive employee behavior that significantly benefits the organization, namely perceptions of organizational justice in addition to other variables such as job satisfaction, organizational commitment, personality characteristics, task characteristics, and leadership behavior (Meiyani \& Putra, 2019; Arfah \& Putra, 2019; Tran, Lee, Nguyen, \& Srisittiratkul, 2020). Results of meta-analysis conducted by Emami et al. (2012) on 28 previous studies also concluded that one of the variables of attitude that most influences OCB is the perception of fairness, organizational commitment, and supportive leadership, and job satisfaction (Islam, Bangish, Muhammad, \& Jehan, 2016; Lee, 2018).

Meiyani and Putra (2019) describe that Fairness, justice perceptions as a concept that has meaning as an employee's feeling whether the organization's decision making is done relatively with the input needed by the employee (usually referred to as procedural justice) and whether the employee feels or not that he is valued relatively based on the level of training, tenure, responsibility, and workload (workload) which is usually referred to as distributive justice, where this perception of truth will have a real positive effect on OCB (Kashif, Khan, \& Rafi, 2011). The description, both obtained findings that are reinforcing that organizational justice or the perception of fairness is one crucial determinant variable of OCB employees. Thus, the understanding of equality or organizational justice, with its various forms (procedural and distributive justice), has been recognized, and many have proven to be determinants for the growth of OCB behavior, which will have further implications on employee performance and organizational performance.

Some researchers (e.g., Yang \& Kim, 2018; Arfah \& Putra, 2019; Meiyani \& Putra, 2019; Lambert, Keena, Leone, May, \& Haynes, 2019; Kim \& Chung, 2019) have proven that fair treatment is closely related to work behavior and the achievement of higher performance and job satisfaction. Research conducted by El Hachem and De Giovanni (2019) and Raja, Sheikh, Abbas, and Bouckenooghe, (2018) states that distributive justice influences feelings of fairness towards the result, which affects performance and job satisfaction. Other studies show that individuals will display higher levels of performance and commitment, increased work and payment satisfaction, increased levels of trust, and attitudes of members of the organization when they feel that the decision-making process is fair, and they are treated fairly as well. Research by Heffron (2018) also reinforces the proven results of the research hypothesis testing that distributive justice, procedural justice, and interactional justice simultaneously have a significant effect on 
employee job satisfaction in the tax sector, which means that the higher the perceived justice of employees, the more the sense of achievement felt by them in carrying out his work.

\subsection{Effect of Job Satisfaction on Organizational Commitment, OCB and Employee Performance}

Job satisfaction will have an impact on organizational performance (Ueno \& Krause, 2018). The quality of employee performance requires a precondition of job satisfaction, as stated by Robbins in 2007 that for organizational performance to be achieved, employees should get satisfaction in working first (Chandra, 2016; Andreassen, Hetland, \& Pallesen, 2010). Several of debate has arisen regarding the relationship between job satisfaction and performance. Empirical findings regarding the relationship between job satisfaction and performance are examined further in such studies. Several studies (e.g., Fisher, 2010; Hoendervanger et al., 2019; Hayati \& Caniago, 2012; Jamrozik, Clements, Hasan, Zhao, Zhang, Campanella, \& Bauer, 2019) show that job satisfaction has a significant positive effect on performance. Some other factors that affect employee performance are organizational culture, motivation, job satisfaction, and work commitment. The relationship between satisfaction and performance per expectations occurs based on the thought that with good performance employees will get awards such as promotions, incentives and so on so that it becomes a driver of job satisfaction (Arfah \& Putra, 2019). Some findings are at odds with the results of a meta-analysis of Bono and Judge (2003) states that there is a correlation between job satisfaction with performance, but only a form of relationship, but it is not found that job satisfaction can improve performance.

Organizational commitment is needed, especially when employees and organizations want to maintain a working relationship between them. Responsibility as an obligation felt by employees to remain in the organization. Commitment relates to organizational citizenship. An employee with a strong commitment has the confidence to serve an organization with a high level of loyalty. They feel that this is their duty and obligation (Zayas-Ortiz, Rosario, Marquez, \& Colón Gruñeiro, 2015; Meyer, Morin, \& Vandenberghe, 2015; Giorgetti, Lajoie, Carter, Attia, Zhan, $\mathrm{Xu}, \&$ Heard, 2016). OCB is an essential factor that can contribute to the survival of an organization. Ignoring OCB in organizations can result in low perception of organizational support, the conflict between employees and managers characterized by employee anxiety when working, boss-subordinate interactions that are less harmonious. Based on contemporary management literature shows that
OCB influences overall organizational effectiveness (Walz $\&$ Niehoff, 1996). Based on the theoretical studies that have been put forward, the proposed research conceptual framework model is as follows (see Figure 1):

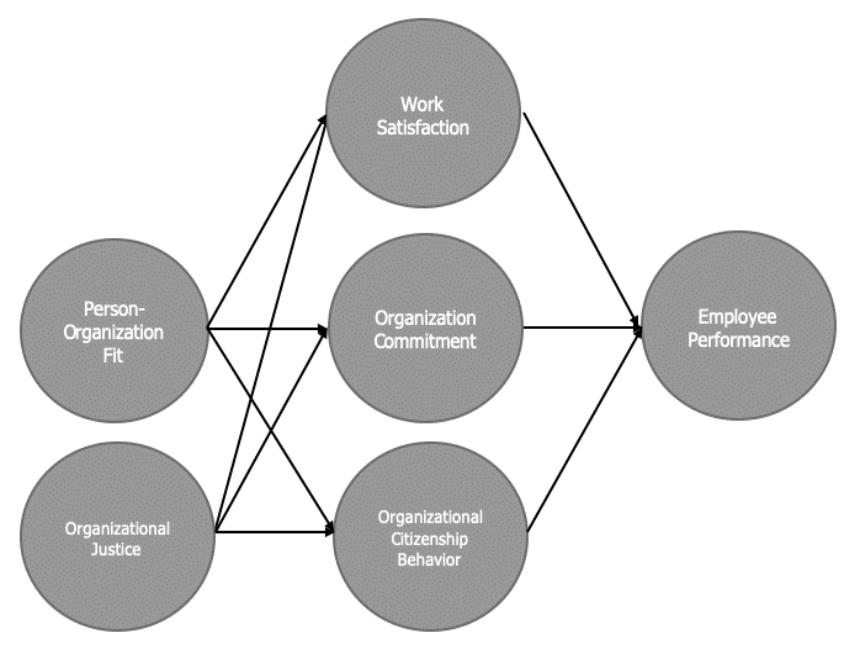

Figure 1: Research Framework

\section{Research Methods and Materials}

\subsection{Samples}

The location to research SOE's in Indonesia with the object under study is the employees of the three main SOE's, namely Pelindo-IV. Ltd, Pertamina. Ltd and Telkom. Ltd. Data is collected at the Head Office of each SOE's that operates in Makassar City, South Sulawesi, Indonesia. The study population was all non-managerial permanent employees. The reason for choosing non-managerial employees is because the employees in this section, which directly carry out all the policies that have been made by the company. For this reason, the effectiveness of a system is highly dependent on their willingness, effort, and ability to implement the policy. Determination of the number of samples carried out evenly from each company that is as many as 30 people so that the total sample of 90 people. The sample selection used simple random sampling.

\subsection{Measurement}

The main instrument in collecting data in this study is structured of the questionnaire developed from various previous studies, then re-tested its reliability and validity. Some questionnaires are Closes-ended question, which is a form of items that have been prepared by various alternative answer choices, and some are Open-Ended Questions. The answers to each issue raised are organized 
into Five alternative explanations with an answer scale ranging from 1 (strongly disagree) - 5 (strongly agree) on the Likert Scale (Indahingwati, Launtu, Tamsah, Firman, Putra, \& Aswari, 2019). The variable measurement instrument is explained in detail in Table 1.

Data analysis was carried out through two stages, the first stage, which was descriptive quantitative data analysis sourced from a census conducted on people who were made respondents. In this quantitative study, data processing is carried out through the stages of inspection (editing), the process of categorizing or classifying data (coding), and the process of disclosure (tabulating) and then analyzed using the Structural Equation Modeling (SEM) approach. Several stages of testing the study include testing confirmatory factor analysis (confirmatory factor analysis).

Tabel 1: Measurement of Variables

\begin{tabular}{|c|c|c|}
\hline Variables & Code & Items \\
\hline $\begin{array}{l}\text { Person- } \\
\text { Organization } \\
\text { Fit (X1) }\end{array}$ & $\begin{array}{l}\mathrm{X} 1.1 \\
\mathrm{X} 1.2 \\
\mathrm{X} 1.3 \\
\mathrm{X} 1.4\end{array}$ & $\begin{array}{c}\text { Value congruence } \\
\text { Goal congruence } \\
\text { Employee need fulfillment } \\
\text { Culture personality congruence }\end{array}$ \\
\hline $\begin{array}{l}\text { Organizational } \\
\text { Justice (X2) }\end{array}$ & $\begin{array}{l}\mathrm{X} 2.1 \\
\mathrm{X} 2.2 \\
\mathrm{X} 2.3\end{array}$ & $\begin{array}{l}\text { Distributive Justice } \\
\text { Procedural Justice } \\
\text { Inter-sactional Justice }\end{array}$ \\
\hline $\begin{array}{c}\text { Work } \\
\text { Satisfaction } \\
\text { (Y1) }\end{array}$ & $\begin{array}{l}\text { Y1.1 } \\
\text { Y1.2 } \\
\text { Y1.3 } \\
\text { Y1.4 } \\
\text { Y1.5 }\end{array}$ & $\begin{array}{l}\text { Take home payment } \\
\text { The work itself } \\
\text { Co-workers } \\
\text { Career Promotion } \\
\text { Supervision }\end{array}$ \\
\hline $\begin{array}{l}\text { Organizational } \\
\text { Commitment } \\
\text { (Y2) }\end{array}$ & $\begin{array}{l}\mathrm{Y} 2.1 \\
\mathrm{Y} 2.2 \\
\mathrm{Y} 2.3\end{array}$ & $\begin{array}{l}\text { Affective Commitment } \\
\text { Continuance Commitment } \\
\text { Normative Commitment }\end{array}$ \\
\hline $\begin{array}{l}\text { Organizational } \\
\text { Citizenship } \\
\text { Behavior (Y3) }\end{array}$ & $\begin{array}{l}\text { Y3.1 } \\
\text { Y3.2 } \\
\text { Y3.3 } \\
\text { Y3.4 } \\
\text { Y3.5 }\end{array}$ & $\begin{array}{c}\text { Alturism } \\
\text { Conscientiousness } \\
\text { Sportmanship } \\
\text { Courtesy } \\
\text { Civic Virtue }\end{array}$ \\
\hline $\begin{array}{l}\text { Employee } \\
\text { Performance } \\
\text { (Y4) }\end{array}$ & $\begin{array}{l}\text { Y } 4.1 \\
\text { Y } 4.2 \\
\text { Y } 4.3 \\
\text { Y4.4 }\end{array}$ & $\begin{array}{c}\text { Work Quantity } \\
\text { Work Quality } \\
\text { Knowledge about Job Descption } \\
\text { Job responsibility }\end{array}$ \\
\hline
\end{tabular}

On each latent variable, namely person-organization fit (X1); organizational justice (X2); job satisfaction (Y1), organizational commitment (Y2), OCB (Y3), and employee performance (Y4) using the AMOS program. If the value of the factor load on the indicator is more significant than 0.4, then the indicator can be used to measure variables. Furthermore, reliability testing, the goodness of fit models (Chi-square, CMIN-DF, RMSEA, GFI, AGFI, TLI, CFI). Furthermore, T-Value and P-Value testing for hypothesis testing (Razak, Hidayat, Launtu, Kusuma Putra, \& Bahasoan, 2020; Firman, Mustapa, Ilyas, \& Putra, 2020).

\section{Results and Discussion}

\subsection{Statistical Results}

Table 2 shows the confirmatory testing of all variables and indicators above 0.5 so that it can be concluded that all indicators can be used to measure the variables and can be used for further analysis.

Tabel 2: Confirmatory Factor Analysis

\begin{tabular}{|c|c|c|c|c|c|}
\hline Variables & $\begin{array}{c}\text { Code } \\
\text { Indicator }\end{array}$ & $\begin{array}{l}\text { Loading } \\
\text { Factor } \lambda\end{array}$ & $\lambda^{2}$ & $\begin{array}{c}\text { Standar } \\
\text { Error } \\
\left(1-\lambda^{2}\right)\end{array}$ & $\begin{array}{l}\text { Critic } \\
\text { al } \\
\text { Ratio }\end{array}$ \\
\hline \multirow{5}{*}{$\begin{array}{c}\text { Person- } \\
\text { Organizatio } \\
\text { n Fit (X1) }\end{array}$} & $\mathrm{X} 11$ & 0.697 & 0.486 & 0.514 & \multirow{5}{*}{0.834} \\
\hline & $\mathrm{X} 12$ & 0.889 & 0.790 & 0.210 & \\
\hline & $\mathrm{X} 13$ & 0.844 & 0.712 & 0.288 & \\
\hline & $\mathrm{X} 14$ & 0.788 & 0.621 & 0.379 & \\
\hline & Total & 3.218 & & 1.391 & \\
\hline \multirow{4}{*}{$\begin{array}{l}\text { Organizatio } \\
\text { nal Justice } \\
\text { (X2) }\end{array}$} & $\mathrm{X} 21$ & 0.825 & 0.681 & 0.319 & \multirow{4}{*}{0.741} \\
\hline & $\mathrm{X} 22$ & 0.798 & 0.637 & 0.363 & \\
\hline & $\mathrm{X} 23$ & 0.806 & 0.650 & 0.350 & \\
\hline & Total & 2.429 & & 1.033 & \\
\hline \multirow{6}{*}{$\begin{array}{c}\text { Work } \\
\text { Satisfaction } \\
\text { (Y1) }\end{array}$} & Y11 & 0.736 & 0.542 & 0.458 & \multirow{6}{*}{0.865} \\
\hline & Y12 & 0.808 & 0.653 & 0.347 & \\
\hline & Y13 & 0.853 & 0.728 & 0.272 & \\
\hline & Y14 & 0.812 & 0.659 & 0.341 & \\
\hline & Y15 & 0.421 & 0.177 & 0.823 & \\
\hline & Total & 3.630 & & 2.241 & \\
\hline \multirow{4}{*}{$\begin{array}{l}\text { Organizatio } \\
\text { nal } \\
\text { Commitmen } \\
\text { t (Y2) }\end{array}$} & $\mathrm{Y} 21$ & 0.768 & 0.590 & 0.410 & \multirow{4}{*}{0.692} \\
\hline & Y22 & 0.643 & 0.413 & 0.587 & \\
\hline & $\mathrm{Y} 23$ & 0.739 & 0.546 & 0.454 & \\
\hline & Total & 2.150 & & 1.451 & \\
\hline \multirow{6}{*}{$\begin{array}{c}\text { Organizatio } \\
\text { nal } \\
\text { Citizenship } \\
\text { Behavior } \\
\text { (Y3) }\end{array}$} & Y31 & 0.795 & 0.632 & 0.368 & \multirow{6}{*}{0.087} \\
\hline & Y32 & 0.829 & 0.687 & 0.313 & \\
\hline & Y33 & 0.823 & 0.677 & 0.323 & \\
\hline & Y34 & 0.762 & 0.581 & 0.419 & \\
\hline & Y35 & 0.805 & 0.648 & 0.352 & \\
\hline & Total & 4.014 & & 1.775 & \\
\hline \multirow{5}{*}{$\begin{array}{c}\text { Employee } \\
\text { Performance } \\
\text { (Y4) }\end{array}$} & Y41 & 0.800 & 0.640 & 0.360 & \multirow{5}{*}{0.786} \\
\hline & Y42 & 0.819 & 0.671 & 0.329 & \\
\hline & Y43 & 0.595 & 0.354 & 0.646 & \\
\hline & Y44 & 0.535 & 0.286 & 0.714 & \\
\hline & Total & 2.749 & & 2.049 & \\
\hline
\end{tabular}


While Table 3 describes the suitability of the model (goodness of fit) the results obtained in Table 3 show that the seven criteria used to assess the feasibility of a model turned out to be the majority of the requirements fulfilled; thus, the results of this analysis can be continued at the next stage. It can be assumed that the model is acceptable, which means there is a match between the model and the data.

Tabel 3: Goodness of Fit Test

\begin{tabular}{|c|c|c|c|}
\hline Criteria & Cut-Off Value & Result & Info \\
\hline Chi-Square & $\begin{array}{c}\mathrm{X}^{2} \text { with } \mathrm{df}=220,= \\
255,602\end{array}$ & 198,708 & Good \\
\hline Probability & $\geq 0,05$ & 0,846 & Good \\
\hline CMIN-DF & $\leq 2,00$ & 0,903 & Good \\
\hline RMSEA & $\leq 0,08$ & 0,000 & Good \\
\hline GFI & $\geq 0,90$ & 0,856 & Good \\
\hline AGFI & $\geq 0,90$ & 0,804 & Moderate \\
\hline TLI & $\geq 0,95$ & 1,029 & Good \\
\hline CFI & $\geq 0,95$ & 1,000 & Good \\
\hline
\end{tabular}

The structural model testing shows the T-value (Critical Ratio) of the majority of the variable relationship path shows the $\mathrm{CR}$ value $<1.960$ which indicates a positive and significant effect, except the relationship between personorganization fit on organizational commitment and OCB, shows no significant impact based on CR values which is smaller than 1,960. The red line shows the path of the relationship, which has no significant effect (see Figure 2). Detailed interpretation of Figure 2 is also explained in Table 4 and 5 in hypothesis testing.



Figure 2: Structural Equation Model Test

Table 4 shows that the coefficient of influence of the variable organization person fit (X1) on job satisfaction (Y1) is 0.450 , with $\mathrm{t}$-value of 2.560 . The coefficient shows that the variable person-organization fit (X1) has a positive effect on job satisfaction (Y1). This means that an increase in person-organization fit (X1), will be followed by an increase in job satisfaction (Y1), assuming other factors that affect the size of job satisfaction are considered constant. The statistical value of t-value the effect of personorganization fit (X1) on job satisfaction (Y1) of 2.560, with a probability value of 0.010 . This means that personorganization fit (X1) has a positive and significant effect on job satisfaction (Y1).

Tabel 4: Result of Structural Model Analysis of Realtionship Intra-Variables

\begin{tabular}{|c|c|c|c|c|}
\hline Path analysis & Estimate & $\begin{array}{l}\text { T-value } \\
\text { (Critical } \\
\text { Ratio) }\end{array}$ & $\begin{array}{c}p- \\
\text { value }\end{array}$ & Info \\
\hline $\begin{array}{l}\text { Person-Organization } \\
\text { Fit } \rightarrow \text { Work } \\
\text { Satisfaction }\end{array}$ & 0,450 & 2,560 & 0,010 & Supported \\
\hline $\begin{array}{l}\text { Person-Organization } \\
\text { Fit } \rightarrow \text { Organizational } \\
\text { Commitment }\end{array}$ & 0,213 & 0,971 & 0,331 & $\begin{array}{c}\text { Not } \\
\text { Supported }\end{array}$ \\
\hline $\begin{array}{l}\text { Person-Organization } \\
\text { Fit } \rightarrow \text { OCB }\end{array}$ & 0,192 & 0,854 & 0,393 & $\begin{array}{c}\text { Not } \\
\text { Supported }\end{array}$ \\
\hline $\begin{array}{c}\text { Organizational } \\
\text { Commitment } \rightarrow \\
\text { Organizational } \\
\text { Commitment }\end{array}$ & 0,228 & 2,389 & 0,017 & Supported \\
\hline $\begin{array}{l}\text { Organizational Justice } \\
\quad \rightarrow \text { OCB }\end{array}$ & 0,199 & 2,208 & 0,027 & Supported \\
\hline $\begin{array}{l}\text { Organizational } \\
\text { Commitment } \rightarrow \text { Work } \\
\text { satisfaction }\end{array}$ & 0,228 & 3,143 & 0.002 & Supported \\
\hline $\begin{array}{c}\text { Organizational } \\
\text { Commitment } \rightarrow \\
\text { Employee Performance }\end{array}$ & 0,347 & 2,919 & 0,004 & Supported \\
\hline $\begin{array}{l}\text { Work satisfaction } \rightarrow \\
\text { Employee Performance }\end{array}$ & 0,405 & 2,049 & 0,040 & Supported \\
\hline $\begin{array}{l}\text { OCB } \rightarrow \text { Employee } \\
\text { Performance }\end{array}$ & 0,242 & 2,352 & 0.019 & Supported \\
\hline \multicolumn{4}{|c|}{ Indirect Effect } & Value \\
\hline \multicolumn{4}{|c|}{$\begin{array}{l}\text { The indirect effect of variables person-organization fit on } \\
\text { employee performance through job satisfaction, } \\
\text { organizational commitment, and OCB }\end{array}$} & 0.187 \\
\hline \multicolumn{4}{|c|}{$\begin{array}{l}\text { The indirect effect of organizational justice variables on } \\
\text { employee performance through job satisfaction, } \\
\text { organizational commitment, and OCB }\end{array}$} & 0.343 \\
\hline
\end{tabular}

The coefficient of influence of the variable organization person fit (X1) on organizational commitment (Y2) is 0.213 , with t-value of 0.971 and a probability value of 0.331 . This means that person-organization fit (X1) has no significant effect on organizational commitment (Y2). The coefficient 
of influence of the variable organization person fit (X1) to OCB (Y3) is 0.192 with a $t$ value of 0.854 and a probability value of 0.393 . This means that person-organization fit (X1) has no significant effect on OCB (Y3). The coefficient of influence of organizational justice variables (X2) on organizational commitment (Y2) is 0.228 , with a t value of 2.389. The coefficient shows that the organizational justice variable (X2) has a positive effect on organizational commitment (Y2). The coefficient of influence of the organizational justice variable (X2) on OCB (Y3) is 0.199 , with $t$-value of 2.208. The coefficient shows that the organizational justice variable (X2) has a positive effect on OCB (Y3).

Tabel 5: Hypothesis Result

\begin{tabular}{|c|c|c|}
\hline H1 & $\begin{array}{c}\text { Hyphotesis } \\
\text { Person-organization fit has a positive and } \\
\text { significant effect on job satisfaction, } \\
\text { organizational commitment, OCB, and employee } \\
\text { performance }\end{array}$ & $\begin{array}{c}\text { Not } \\
\text { Supported }\end{array}$ \\
\hline H2 & $\begin{array}{c}\text { Organizational justice has a positive and } \\
\text { significant effect on organizational commitment, } \\
\text { OCB, and employee performance. }\end{array}$ & Supported \\
\hline H3 & $\begin{array}{c}\text { Job satisfaction, organizational commitment, OCB } \\
\text { has a positive and significant effect on employee } \\
\text { performance. }\end{array}$ & Supported \\
\hline
\end{tabular}

The coefficient of influence of organizational justice variables (X2) on job satisfaction (Y1) is 0.228 , with a $t$ value of 3.143 with a probability value of 0.002 . The coefficient shows that the organizational justice variable (X2) has a positive effect on job satisfaction (Y1). The coefficient of influence of organizational commitment variable (Y2) on employee performance (Y4) of 0.347 with $\mathrm{t}$-value of 2.919. The coefficient indicates that the variable organizational commitment (Y2) has a positive effect on employee performance (Y4). The coefficient of influence of the variable job satisfaction (Y1) on employee performance (Y4) of 0.405 with t-value of 2.049. The coefficient indicates that the variable job satisfaction (Y1) has a positive effect on employee performance (Y4). The coefficient of influence of the OCB variable (Y3) on employee performance (Y4) is 0.242 with $t$-value of 2.352 . The coefficient shows that the OCB variable (Y3) has a positive effect on employee performance (Y4).

In the indirect relationship, the influence of personorganization fit on employee performance through job satisfaction, organizational commitment, and OCB is 0.187 , so it can be stated that job satisfaction, organizational commitment, and OCB as intervening variables are strengthening the person-organization fit variable on employee performance. The effect of organizational justice on employee performance through job satisfaction, organizational commitment, and OCB is 0.343 , so it can be stated that job satisfaction, organizational commitment, and OCB as an intervening variable are strengthening organizational justice variables on employee performance.

\subsection{Discussion}

Person-organizational fit has a positive and significant effect on job satisfaction. This explains that the higher the Person-Organizational Fit, the higher the employee satisfaction. Thus, employees will be happy to work in jobs that are following their competencies and organizational values that are commensurate with their benefits. This finding also reinforces the principle of the right man in the right place, so it needs to be implemented optimally in the SOE sector companies that are the object of this study. However, person-organizational fit does not have a significant effect on organizational commitment indicating that the compatibility factor between individual and organizational values, the compatibility of employee competencies with work, is not a guarantee for employees to commit or not committed to the organization and its goals. This can happen because, organizational commitment is not only based on commitment or affective commitment, it is also based on continuity commitment, namely consideration of the presence or absence, or the size of the opportunity to get other better jobs outside the company and normative commitments.

Likewise, the relationship that explains the relationship between a person-organizational fit that does not influence OCB means that whether or not a person is fit for work or organization is no guarantee of OCB's growth or failure. OCB's behavior is other work behavior and an excellent helping nature to help coworkers, asked or not asked, but voluntarily he does. Helping other people (coworkers) can be done in a variety of forms, both relevant and irrelevant to their main tasks according to their competencies or not. Thus OCB, as a personality trait likes to help others, does not require compatibility requirements, especially competence to do it. OCB behavior (generosity or selfless help) can occur as a spontaneity, to anyone, anytime and anywhere within the scope of the organization in which it interacts.

The relationship between organizational justice has a positive and significant effect on organizational commitment, OCB and job satisfaction means that the more equitable treatment of employees both distributive, procedural and interactional will further strengthen employee attachment to the organization both mentally/emotionally (affective commitment) and physically, both because of conscience considerations (emotional involvement), profit and loss (continuance commitment) and rules (normative commitment). In line 
with this, the higher the fair treatment felt by employees, the more fostering work behavior (extra-work) to complete their work even outside the demands of their work. Likes to help other employees to complete their work without expecting any reward or repayment from assisted coworkers. The pleasure to help others finish their work will be higher among individuals or employees who feel the fair treatment of their organization.

Therefore, the fairer treatment of employees will further increase employee job satisfaction. Conversely, injustice in treating employees will have an impact on employee dissatisfaction at work. Employees will undoubtedly feel happy working in a non-discriminatory work environment, and this will foster work enthusiasm to achieve superior performance because they believe that their performance will be valued equally between the results obtained with the input or they sacrifice provide. Whoever works a lot will earn more rewards, but those who work less will receive a little award (Khalid \& Shoaib, 2019).

High organizational commitment is marked among others by the existence of strong emotional ties from employees to help the organization achieve its goals because they consider themselves to be part of the organization. That is responsible and receives benefits for the success of the organization; on the contrary, it will also bear the loss of organizational failure. If employees firmly hold these feelings, they will work enthusiastically to maximize the results, and they can contribute to the organization.

This study also revealed that job satisfaction has a positive effect on employee performance. This finding means that the more satisfied employees are at everything received from the company (salary, promotion, supervision, relationships with colleagues and jobs that are suitable and enjoyable) will encourage them to perform better. In line with this, on the other hand, OCB also has a positive influence on employee performance. In other words, an increase in OCB will be followed by an increase in employee performance. Employees who have high OCB will manifest in the form of work behavior that is willing and willing to help. They want to do work beyond the standard set for him without intending to get praise, awards, let alone financial rewards but solely because of the sincerity that comes from within employees. Of course, if the employee likes helping others, coworkers, or anyone else, then, of course, his work will be completed much more perfect before assisting others in perfecting their work.

\subsection{Theorethical and Managerial Implication}

Following the motivational theory proposed by Herzberg who found several factors causing employee job dissatisfaction stemming from the extrinsic factor of company policy and administration, supervision, interpersonal relations, and working conditions (Ewen, 1964; Gawel, 1997; DeShields, Kara, \& Kaynak, 2005; Milliman, Gatling, \& Kim, 2018; Wilms, Winnen, \& Lanwehr, 2019). This study implies that the factor of fair treatment or organizational justice (both distributive, procedural justice) can be categorized as a policy and regulatory factor as well as interactional justice, which can also be classified as a factor of interpersonal relations. This means that if this is not met, then there will be job dissatisfaction, which will have further implications on the resulting performance. Job satisfaction factors are achievement, recognition, work itself, responsibility, advancement, and growth, where the work factor itself includes job suitability.

In the concept of ideal human resource management, justice is a principle that plays an essential role in creating positive performance, so that employee engagement can be fulfilled to build a better and optimal organization (Meiyani \& Putra, 2019; Ramlawati \& Putra, 2018)

\section{Conclusions}

Structurally there is a significant direct effect of PersonOrganization Fit on job satisfaction but not significantly on organizational commitment and OCB. This has a further impact on its indirect effect, where Person-Organization Fit only significantly influences employee performance through job satisfaction while organizational commitment and OCB is also insignificant. In other words, PersonOrganization Fit must be accompanied by the satisfaction felt by employees in working to be able to perform better. Apart from that, organizational justice has a significant and positive effect on job satisfaction, organizational commitment, and $\mathrm{OCB}$, so that it has further positive implications for employee performance. Indirectly, the variable job satisfaction, organizational commitment, and OCB are also significant as a mediator of employee performance. This means that organizational justice coupled with job satisfaction, organizational commitment, and OCB, will be increasingly able to make employees achieve better performance.

\section{References}

Afsar, B., Badir, Y., \& Khan, M. M. (2015). Person-job fit, person-organization fit and innovative work behavior: The mediating role of innovation trust. The Journal of High Technology Management Research, 26(2), 105-116. https://doi.org/10.1016/j.hitech.2015.09.001

Akram, T., Lei, S., Haider, M. J., \& Hussain, S. T. (2019). The impact of organizational justice on employee innovative work 
behavior: Mediating role of knowledge sharing. Journal of Innovation \& Knowledge. (in-press).

https://doi.org/10.1016/j.jik.2019.10.001

Andreassen, C. S., Hetland, J., \& Pallesen, S. (2010). The relationship between 'workaholism', basic needs satisfaction at work and personality. European Journal of Personality: The European Association of Personality Psychology, 24(1), 3-17.

Arfah, A., \& Putra, A. H. P. K. (2019). Analysis of Productivity and Distribution of Female Workers in FB's Industries. Journal of Distribution Science, 17(3), 31-39. https://doi.org/10.15722/jds.17.3.201903.31

Bagozzi, R. P., \& Verbeke, W. J. M. I. (2019). Genetic and psychological underpinnings of motivation and satisfaction of industrial salespeople. Industrial Marketing Management. (inpress). https://doi.org/10.1016/j.indmarman.2019.08.011

Bono, J. E., \& Judge, T. A. (2003). Core self-evaluations: A review of the trait and its role in job satisfaction and job performance. European Journal of Personality, 17(1), 5-18. https://doi.org/10.1002/per.481

Brass, D. J. (1984). Being in the right place: A structural analysis of individual influence in an organization. Administrative Science Quarterly, 29(4), 518-539. http://dx.doi.org/10.2307/2392937

Chandra, T. (2016). The Influence of Leadership Styles, Work Environment and Job Satisfaction of Employee PerformanceStudies in the School of SMPN 10 Surabaya. International Education Studies, 9(1), 131-140. https://doi.org/10.5539/ies.v9n1p131

Choi, H.-M., Kim, W. G., \& McGinley, S. (2017). The extension of the theory of person-organization fit toward hospitality migrant worker. International Journal of Hospitality Management, 62(1), 53-66. https://doi.org/10.1016/j.ijhm.2016.12.003

CNN Indonesia. (2019). Uncovering the Root of the Problem of Corruption Causes of BUMN Directors. Retrieved December 29, 2019, from

https://www.cnnindonesia.com/ekonomi/20191004063546-92436640/menyibak-akar-masalah-penyebab-korupsi-direksibumn

Cohen-Charash, Y., \& Spector, P. E. (2001). The role of justice in organizations: A meta-analysis. Organizational Behavior and Human Decision Processes, 86(2), 278-321. https://doi.org/10.1006/obhd.2001.2958

Daugherty, P. J., Chen, H., \& Ferrin, B. G. (2011). Organizational structure and logistics service innovation. The International Journal of Logistics Management, 22(1), 26-51. https://doi.org/10.1108/091111127543

Deniz, N., Noyan, A., \& Ertosun, Ö. G. (2015). Linking Personjob Fit to Job Stress: The Mediating Effect of Perceived Person-organization Fit. Procedia - Social and Behavioral Sciences, 207(October), 369-376. https://doi.org/10.1016/j.sbspro.2015.10.107

DeShields-Jr, O. W., Kara, A., \& Kaynak, E. (2005). Determinants of business student satisfaction and retention in higher education: applying Herzberg's two-factor theory. International Journal of Educational Management, 19(2), 128-139. https://doi.org/10.1108/09513540510582426

Dougherty, C., \& Kurke, L. (2003). The cultures within ancient Greek culture: Contact, conflict, collaboration. Cambridge,
UK: Cambridge University Press.

El-Hachem, W., \& De Giovanni, P. (2019). Accelerating the transition to alternative fuel vehicles through a Distributive Justice perspective. Transportation Research Part D: Transport and Environment, 75(October), 72-86. https://doi.org/10.1016/j.trd.2019.08.020

Emami, M., Alizadeh, Z., Nazari, K., \& Darvishi, S. (2012). Antecedents and consequences of organisational citizenship behaviour (OCB). Interdisciplinary Journal of Contemporary Research in Business, 3(9), 494-505

Ewen, R. B. (1964). Some determinants of job satisfaction: A study of the generality of Herzberg's theory. Journal of Applied Psychology, 48(3), 161-163. https://doi.org/10.1037/h0048383

Farooqui, M. S., \& Nagendra, A. (2014). The impact of person organization fit on job satisfaction and performance of the employees. Procedia Economics and Finance, 11, 122-129. https://doi.org/10.1016/S2212-5671(14)00182-8

Fisher, C. D. (2010). Happiness at work. International Journal of Management Reviews, 12(4), 384-412. https://doi.org/10.1111/j.1468-2370.2009.00270.x

Firman, A., Mustapa, Z., Ilyas, G. B., \& Putra, A. H. P. K. (2020). Relationship of TQM on Managerial Performance: Evidence From Property Sector in Indonesia. Journal of Distribution Science, 18(1), 47-57. http://dx.doi.org/10.15722/jds.17.12.20201.47

Gawel, J. E. (1997). Herzberg's theory of motivation and Maslow's hierarchy of needs. Practical Assessment, Research \& Evaluation, 5(11), 1-6. https://scholarworks.umass.edu/pare/vol5/iss 1/11

Giorgetti, L., Lajoie, B. R., Carter, A. C., Attia, M., Zhan, Y., Xu, J. Heard, E. (2016). Structural organization of the inactive $X$ chromosome in the mouse. Nature, 535(7613), 575. https://doi.org/10.1038/nature18589

Hayati, K., \& Caniago, I. (2012). Islamic Work Ethic: The Role of Intrinsic Motivation, Job Satisfaction, Organizational Commitment and Job Performance. Procedia - Social and Behavioral Sciences, 65(December), 272-277. https://doi.org/https://doi.org/10.1016/j.sbspro.2012.11.122

Heffron, R. J. (2018). The application of distributive justice to energy taxation utilising sovereign wealth funds. Energy Policy, 122(November), 649-654. https://doi.org/10.1016/j.enpol.2018.07.049

Hirschi, A., Herrmann, A., Nagy, N., \& Spurk, D. (2016). All in the name of work? Nonwork orientations as predictors of salary, career satisfaction, and life satisfaction. Journal of Vocational Behavior, 95-96(August-October), 45-57. https://doi.org/10.1016/j.jvb.2016.07.006

Hoendervanger, J. G., Van Yperen, N. W., Mobach, M. P., \& Albers, C. J. (2019). Perceived fit in activity-based work environments and its impact on satisfaction and performance. Journal of Environmental Psychology, 65(October), 101339. https://doi.org/10.1016/j.jenvp.2019.101339

Ibrahim, M. A. (2014). Relation of Motivation with Organizational Citizenship Behaviour (OCB) in Company BUMN Makassar (Study at PT. Telecommunications Indonesia Area Makassar). Journal of Basic and Applied Scientific Research, 4(12), 97101.

Ibrahim, M. A., \& Aslinda, A. (2013). Relationship between 
organizational commitment and organizational citizenship behavior (OCB) at government-owned corporation companies. Journal of Public Administration and Governance, 3(3), 3542.

Indahingwati, A., Launtu, A., Tamsah, H., Firman, A., Putra, A. H. P. K., \& Aswari, A. (2019). How Digital Technology Driven Millennial Consumer Behaviour in Indonesia. Journal of Distribution Science, 17(8), 25-34. http://dx.doi.org/10.15722/jds.17.08.201908.25

Islam, Z. U., Bangish, S. B., Muhammad, H., \& Jehan, A. S. (2016). The Impact of HR Practices on Job Satisfaction: A Case Study of Hotel Industry in Pakistan. Journal of Asian Finance, Economics and Business, 3(1), 43-48. https://doi.org/10.13106/jafeb.2016.vol3.no1.43

Jamrozik, A., Clements, N., Hasan, S. S., Zhao, J., Zhang, R., Campanella, C., \& Bauer, B. (2019). Access to daylight and view in an office improves cognitive performance and satisfaction and reduces eyestrain: A controlled crossover study. Building and Environment, 165(November), 106379. https://doi.org/10.1016/j.buildenv.2019.106379

Jung, M. H. (2020). The Effect of Social Capital on Personal Happiness: A Focus on Service Inderstry Employees. Journal of Asian, Economics and Business, 7(1), 291-299. https://doi.org/10.13106/jafeb.2020.vol7.no1.291

Kashif, M., Khan, Y., \& Rafi, M. (2011). An Exploration of the Determinants of OCB in the Telecommunication Sector of Pakistan. Asian Journal of Business Management, 3(2), 91-97.

Khalid, K., \& Shoaib, A. (2019). Reward, Satisfaction and Economics Trends Under Nonlinear Assumption. Journal of Asian Finance, Economics and Business, 6(2), 287-289. https://doi.org/10.13106/jafeb.2019.vol6.no2.287

Kim, S. J., \& Chung, E. K. (2019). The effect of organizational justice as perceived by occupational drivers on traffic accidents: Mediating effects of job satisfaction. Journal of Safety Research, 68(February), 27-32. https://doi.org/10.1016/j.jsr.2018.11.001

Kristof-Brown, A. L., Zimmerman, R. D., \& Johnson, E. C. (2005). Consequences of Individuals'fit at Work: A Meta-Analysis of Person-Job, Person-Organization, Person-Group, and PersonSupervisor Fit. Personnel Psychology, 58(2), 281-342. https://doi.org/10.1111/j.1744-6570.2005.00672.x

Kristof, A. L. (1996). Person-organization fit: An integrative review of its conceptualizations, measurement, and implications. Personnel Psychology, 49(1), 1-49.

Lambert, E. G., Keena, L. D., Leone, M., May, D., \& Haynes, S. H. (2019). The effects of distributive and procedural justice on job satisfaction and organizational commitment of correctional staff. The Social Science Journal. (in-press) https://doi.org/10.1016/j.soscij.2019.02.002

Lee, J. Y. (2018). The Effect of Job Characteristics on The Team Creativity of Distribution Companies: Moderating Effects of Transformational Leadership. Journal of Asian Finance, Economics and Business, 5(4), 161-172. https://doi.org/10.13106/jafeb.2018.vol5.no4.161

Liu, B., Tang, T. L.P., \& Yang, K. (2015). When does public service motivation fuel the job satisfaction fire? The joint moderation of person-organization fit and needs-supplies fit. Public Management Review, 17(6), 876-900. https://doi.org/10.1080/14719037.2013.867068
Mattingly, A. N., \& Boyle, C. J. (2019). Salary and entry-level requirements for pharmacy technicians compared with other health technologist and technician occupations in Maryland. Journal of the American Pharmacists Association, 1(1), 15-25. https://doi.org/10.1016/j.japh.2019.09.009

Maysarah, S., \& Rahardjo, M. (2015). The Influence of Organizational Culture, Justice Organization, and Organizational Commitments to Organizational Citizenship Behavior (Study at PT. KAI Operations Area 4 Semarang). Fakultas Ekonomika dan Bisnis, 4(4), 1-14. http://pubs.sciepub.com/jbms/4/3/2

Meiyani, E., \& Putra, A. H. P. K. (2019). The relationship between Islamic leadership on employee engagement distribution in FMCG industry: Anthropology business review. Journal of Distribution Science, 17(5), 19-28.

http://dx.doi.org/10.15722/jds.17.05.201905.19

Meyer, J. P., Morin, A. J. S., \& Vandenberghe, C. (2015). Dual commitment to organization and supervisor: A person-centered approach. Journal of Vocational Behavior, 88(2), 56-72. https://psycnet.apa.org/doi/10.1016/j.jvb.2015.02.001

Milliman, J., Gatling, A., \& Kim, J. (2018). The effect of workplace spirituality on hospitality employee engagement, intention to stay, and service delivery. Journal of Hospitality and Tourism Management, 35(2), 56-65. https://doi.org/10.1016/j.jhtm.2018.03.002

Nazir, S., Shafi, A., Qun, W., Nazir, N., \& Tran, Q. D. (2016). Influence of organizational rewards on organizational commitment and turnover intentions. Employee Relations, 38(4), 596-619. https://doi.org/10.1108/ER-12-2014-0150

Nohe, C., \& Michaelis, B. (2016). Team OCB, leader charisma, and organizational change: A multilevel study. The Leadership Quarterly, 27(6), 883-895. https://doi.org/https://doi.org/10.1016/j.leaqua.2016.05.006

Özçelik, G., \& Fındıklı, M. A. (2014). The Relationship between Internal Branding and Organizational Citizenship Behaviour: The Mediating Role of Person-organization Fit. Procedia Social and Behavioral Sciences, 150(September), 1120-1128. https://doi.org/10.1016/j.sbspro.2014.09.127

Pérez-Rodríguez, V., Topa, G., \& Beléndez, M. (2019). Organizational justice and work stress: The mediating role of negative, but not positive, emotions. Personality and Individual Differences, 151(1), 109392. https://doi.org/10.1016/j.paid.2019.04.047

Raja, U., Sheikh, R. A., Abbas, M., \& Bouckenooghe, D. (2018). Do procedures really matter when rewards are more important? A Pakistani perspective on the effects of distributive and procedural justice on employee behaviors. European Review of Applied Psychology, 68(2), 79-88. https://doi.org/10.1016/j.erap.2018.03.001

Ramlawati, R., \& Putra, A. H. P. K. (2018). Total Quality Management as the Key of the Company to Gain the Competitiveness, Performance Achievement and Consumer Satisfaction. International Review of Management and Marketing, 8(5), 60-69. https://doi.org/10.32479/irmm.6932

Razak, M., Hidayat, M., Launtu, A., Kusuma Putra, A. and Bahasoan, S. (2020), "Antecedents and consequence of brand management: empirical study of Apple's brand product." Journal of Asia Business Studies [Online First]. https://doi.org/10.1108/JABS-01-2019-0030 
Robst, J., \& VanGilder, J. (2016). Salary and job satisfaction among economics and business graduates: The effect of match between degree field and job. International Review of Economics Education, 21(January), 30-40. https://doi.org/10.1016/j.iree.2015.11.001

Saether, E. A. (2019). Motivational antecedents to high-tech R\&D employees' innovative work behavior: Self-determined motivation, person-organization fit, organization support of creativity, and pay justice. The Journal of High Technology Management Research, 30(2), 100350. https://doi.org/10.1016/j.hitech.2019.100350

Sha, F., Li, B., Law, Y. W., \& Yip, P. S. F. (2019). Beyond the Resource Drain Theory: Salary satisfaction as a mediator between commuting time and subjective well-being. Journal of Transport \& Health, 15(December), 100631. https://doi.org/10.1016/j.jth.2019.100631

Sharma, G. G., \& Stol, K.J. (2020). Exploring onboarding success, organizational fit, and turnover intention of software professionals. Journal of Systems and Software, 159(January), 110442. https://doi.org/10.1016/j.jss.2019.110442

Shin, Y., \& Hur, W. M. (2019). Linking flight attendants' job crafting and OCB from a JD-R perspective: A daily analysis of the mediation of job resources and demands. Journal of Air Transport Management, 79(August), 101681. https://doi.org/10.1016/j.jairtraman.2019.101681

Singh, S., Attri, G., Kanti-Das, K., Jaiswal, S., \& Jaiswal, K.A. (2019). Ectopic pituitary adenoma: The lost track of Ciurea or the right man at wrong place. Interdisciplinary Neurosurgery, (In-press), 100567. https://doi.org/10.1016/j.inat.2019.100567

Tran, D. T., Lee, L. Y., Nguyen, P. T., \& Srisittiratkul, W. (2020). How Leader Characteristics and Leader Member Exchange Lead to Social Capital and Job Performance. Journal of Asian Finance, Economics and Business, 7(1), 269-278. https://doi.org/10.13106/jafeb.2020.vol7.no1.269

Tepeci, M. (2001). The effect of personal values, organizational culture, and person-organization fit on individual outcomes in the restaurant industry ( $\mathrm{PhD}$ Dissertation). The Pensilvania
State University, pp.1-134

Ueno, K., \& Krause, A. (2018). Overeducation, perceived career progress, and work satisfaction in young adulthood. Research in Social Stratification and Mobility, 55(June), 51-62. https://doi.org/10.1016/j.rssm.2018.03.003

Walz, S. M., \& Niehoff, B. P. (1996). Organizational citizenship behaviors and their effect on organizational effectiveness in limited-menu restaurants. Academy of Management Proceedings, Academy of Management Briarcliff Manor, NY 10510. 1(December), pp. 307-311. https://doi.org/10.5465/ambpp.1996.4980770

Wilms, R., Winnen, L. A., \& Lanwehr, R. (2019). Top Managers' cognition facilitate organisational ambidexterity: The mediating role of cognitive processes. European Management Journal, 37(5), 589-600.

https://doi.org/10.1016/j.emj.2019.03.006

Yang, H. C., \& Kim, Y. E. (2018). The Effects of Corporate Social Responsibility on Job Performance: Moderating Effects of Authentic Leadership and Meaningfulness of Work. Journal of Asian Finance, Economics and Business, 5(3) 121-132. https://doi.org/10.13106/jafeb.2018.vol5.no3.121

Yilmaz, O., \& Chen, I.R. (2009). Elastic threshold-based admission control for QoS satisfaction with reward optimization for servicing multiple priority classes in wireless networks. Information Processing Letters, 109(15), 868-875. https://doi.org/10.1016/j.ipl.2009.04.013

Yu, K. Y. T. (2014). Person-organization fit effects on organizational attraction: A test of an expectations-based model. Organizational Behavior and Human Decision Processes, 124(1), 75-94. https://doi.org/10.1016/j.obhdp.2013.12.005

Zayas-Ortiz, M., Rosario, E., Marquez, E., \& Colón Gruñeiro, P. (2015). Relationship between organizational commitments and organizational citizenship behaviour in a sample of private banking employees. International Journal of Sociology and Social Policy, 35(1/2), 91-106. https://doi.org/10.1108/IJSSP02-2014-0010 